\title{
Evaluasi Proses Konsolidasi Tanah Kawasan Permukiman Kumuh Bantaran Sungai Kurau Klaster 1 Desa Kurau Berdasarkan Persepsi Masyarakat
}

\author{
Yurmansah', Mussadun ${ }^{2}$ \\ Diterima :26 Desember 2015 \\ Disetujui :29 Januari 2016
}

\begin{abstract}
Settlement condition of the River Plate Kurau Cluster 1 Kurau slum village made arrangements with land readjustment, but in the implementation of the case back by the public rejection of the result of an agreement or a consensus that settlements be halted. Therefore, it is necessary to evaluate the land consolidation process in order to assess the success of land readjustment process and the factors that hamper implementation. This study uses a mix method with a two-stage procedure. Results of the analysis showed that the land land readjustment process successfully, supported by the success of the equity (score 638), effectiveness (score 631), responsiveness (score 617) and efficiency (579). The success of land land readjustment is caused by, among others, people's desire to stay or do not want to be relocated / displaced, not the status of land ownership society, high support and commitment of local governments and legislators. whereas the factors that hinder the implementation of the agreement of land land readjustment triggered by the inequity in the distribution of location / position of the lots after the land land readjustment of the small percentage of people, causing rejection back public the results of land land readjustment, among others, less efficient and less fair to the size distribution and financing schemes recovery.
\end{abstract}

Keywords: Land readjustment, the slums, the success rate, the evaluation.

\begin{abstract}
ABSTRAK
Kondisi Permukiman Bantaran Sungai Kurau Klaster 1 Desa Kurau yang kumuh dilakukan penataan dengan konsolidasi tanah, namun dalam pelaksanaan terjadi penolakan kembali oleh masyarakat terhadap hasil kesepakatan atau konsesus sehingga penataan permukiman menjadi terhenti. Oleh sebab itu, perlu dilakukan evaluasi proses konsolidasi tanah tersebut guna mengetahui tingkat keberhasilan proses konsolidasi tanah dan faktor-faktor yang menghambat pelaksanaannya. Penelitian ini menggunakan metode campuran (mix method) dengan prosedur dua tahap. Hasil analisis diperoleh bahwa proses konsolidasi tanah berhasil dengan didukung oleh berhasilnya dalam kesetaraan/keadilan (skor 638), efektivitas (skor 631), responsivitas (skor 617) dan efisiensi (579). Keberhasilan konsolidasi tanah ini disebabkan oleh antara lain keinginan masyarakat untuk tetap tinggal atau tidak ingin direlokasi/digusur, status tanah yang bukan kepemilikan masyarakat, tingginya dukungan dan komitmen pemerintah daerah dan DPRD. sedangkan faktor-faktor yang menghambat pelaksanaan hasil kesepakatan konsolidasi tanah dipicu oleh adanya ketidakadilan dalam distribusi letak/posisi kapling setelah konsolidasi tanah terhadap sebagian kecil masyarakat sehingga menimbulkan penolakan kembali masyarakat terhadap hasil konsolidasi tanah antara lain kurang efisien dan kurang adil terhadap distribusi ukuran dan skema pembiayaan pemulihan
\end{abstract}

Kata kunci: Konsolidasi tanah, kawasan kumuh, tingkat keberhasilan, evaluasi.

${ }^{1}$ DPU Kab. Bangka Tengah

Kontak Penulis : yurmansah12@gmail.com

${ }^{2}$ Dosen Magister Pembangunan Wilayah dan Kota, Fakultas Teknik, Universitas Diponegoro 
JPWK 12 (1)Yurmansah Evaluałi Proses Konsolidasi Tanah Kawasan Permukiman Kumuh Bantaran Sungai Kurau Klaster 1 Desa Kurau Berdasarkan Persepsi Masyarakat

\section{PENDAHULUAN}

Konsolidasi tanah sebagai salah satu metode dalam penanganan kawasan kumuh melalui penataan kembali tanah (land readjusment). Kawasan kumuh yang merupakan fenomena yang sering muncul di kota-kota besar adalah tingkat kebutuhan yang tidak seimbang dengan kemampuan kota dalam menyediakan fasilitas umum, sarana dan prasarana lingkungan perumahan. Selain perkotaan kawasan juga tumbuh di wilayah pesisir dan kawasan nelayan, baik dekat muara sungai dekat ke laut maupun pesisir pantai. Permukiman kumuh di bantaran sungai juga terjadi di Desa Kurau Kecamatan Koba Kabupaten Bangka Tengah.

Pada tahun 2012, Pemerintah Kabupaten Bangka Tengah melaksanakan revitalisasi kawasan kumuh di Bantaran Sungai Kurau Klaster 1 Desa Kurau dengan konsolidasi tanah, hal ini sesuai dengan keinginan masyarakat untuk tetap tinggal dan dilaksanakan konsolidasi tanah dalam rangka penataannya, dimana preferensi masyarakat ini dipertimbangkan dari beberapa hal diantaranya aksesibiltas, kenyamanan serta kondisi sarana dan prasarana (Ramdani \& Haryanto,2013) dan Basri (2014). Namun faktanya sampai dengan saat ini pelaksanaan hasil konsolidasi tanah kawasan kumuh bantaran sungai kurau masih belum selesai dilaksanakan bahkan cenderung terhenti, dimana ada penolakan kembali dari masyarakat terhadap hasil kesepakatan atau konsesus sehingga pelaksanaan penataan, pembongkaran dan pembangunan kembali (redevelopment) rumah serta pembangunan infrastruktur dasar tidak dapat dilanjutkan.

Tujuan dari penelitian ini adalah untuk melakukan evaluasi terhadap proses konsolidasi tanah kawasan permukiman kumuh tersebut yang meliputi proses sosialisasi sampai dengan sertifikasi tanah guna mengetahui tingkat keberhasilan proses konsolidasi tanah tersebut dan faktor-faktor yang menghambat pelaksanaan hasil kesepakatan atau konsesus tersebut. Kriteria evaluasi yang digunakan meliputi efektifitas, efisiensi, kesetaraan/keadilan dan responsivitas (Sorensen (2000), Dunn (2003), Kanursay (2004), Turk (2007), Wang (2014), Yilmaz (2015))

\section{METODE PENELITIAN}

Pendekatan penelitian yang digunakan adalah pendekatan positivistik dan bersifat deduktif dengan metode penelitian adalah metode campuran (mix method) dengan strategi metode campuran sekuensial/bertahap (sequensial mix methods). Teknik pengambilan sampel dalam penelitian ini dibagi dalam dua bagian, yaitu teknik probability sampling dan non-probability sampling. Pada teknik probability sampling, teknik yang digunakan adalah Sensus untuk pengambilan data dengan kuisioner dengan responden sebanyak 23 responden. Pada teknik non-probability sampling, digunakan snowball sampling untuk mendapatkan data dengan wawancara mendalam dari informan terpilih.

\section{GAMBARAN UMUM}

Klaster 1 terletak di RT 01 Desa Kurau Kecamatan Koba Kabupaten Bangka Tengah, klaster 1 sebelah utara berbatasan dengan sungai kurau, sebelah barat berbatasan dengan TPI Kurau sebelah selatan berbatasan dengnan jalan setapak dan sebelah timur berbatasan dengan Jalan Masjid Desa Kurau. Luas kawasan klaster 1 yang dilaksanakan Konsolidasi tanah seluas 0,39 Ha dengan jumlah rumah sebanyak 24 rumah. Mayoritas pekerjaan kepala keluarga di klaster 1 
Yurmansah | Evaluasi Proses Konsolidasi Tanah Kawasan Permukiman Kumuh Bantaran Sungai Kurau Klaster 1 Desa Kurau Berdasarkan Persepsi Masyarakat

JPWK 12 (1)

sebagai nelayan dengan pendapatan yang beragam, sebagian besar penduduk di klaster 1 merupakan pendatang. kondisi perumahan bantaran sungai kurau Klaster 1 dinilai sangat kumuh, rumah-rumah menjorok ke sungai sebagai rumah panggung, letak dan posisinya tidak teratur hadapannya bahkan ada yang membelakangi sungai, tanah yang dipakai untuk permukiman belum memiliki kekuatan hukum tetap, infrastruktur permukiman yang belum optimal dimana jaringan air bersih kurang memadai, tidak ada selokan drainase yang memadai, tidak ada tempat sampah yang memadai, pemanfaatan IPAL yang belum optimal, jalan lingkungan tidak terencana dengan baik, tidak ada ruang publik dan ruang terbuka hijau lingkungan, serta tidak ada fasilitas umum yang memadai.

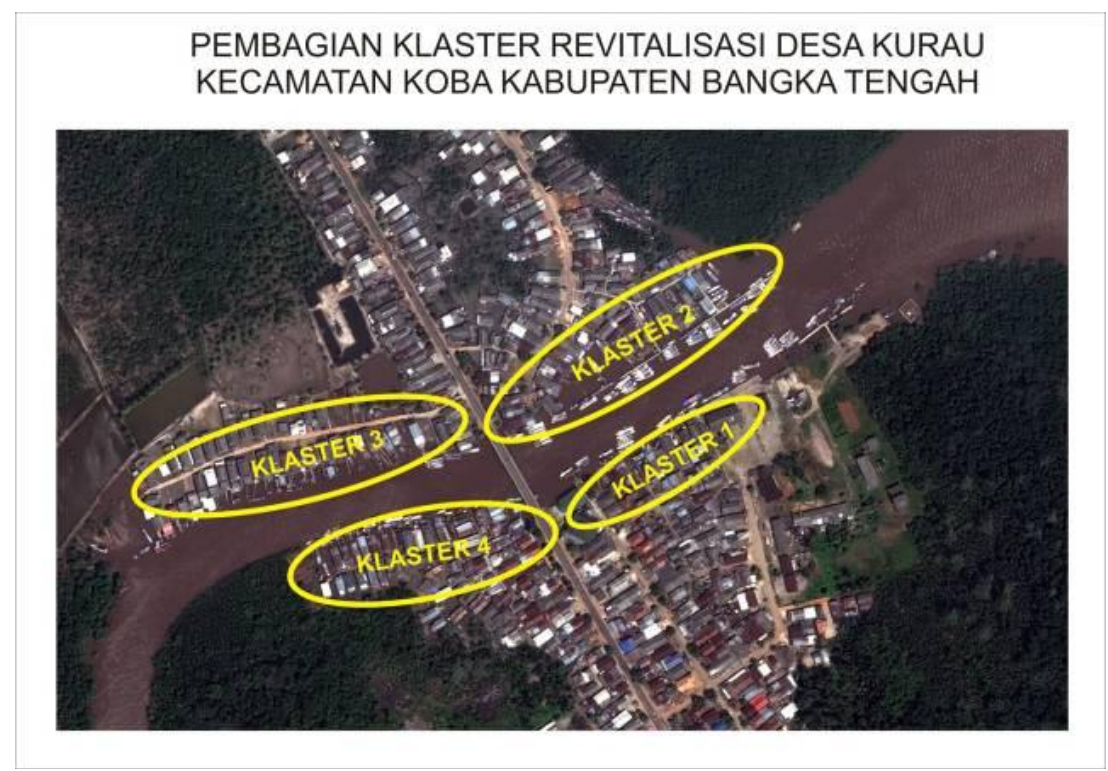

Sumber : Dinas Pekerjaan Umum Kabupaten Bangka Tengah

GAMBAR 1.

PETA LOKASI BANTARAN SUNGAI KURAU KLASTER 1 DESA KURAU KECAMATAN KOBA KABUPATEN BANGKA TENGAH
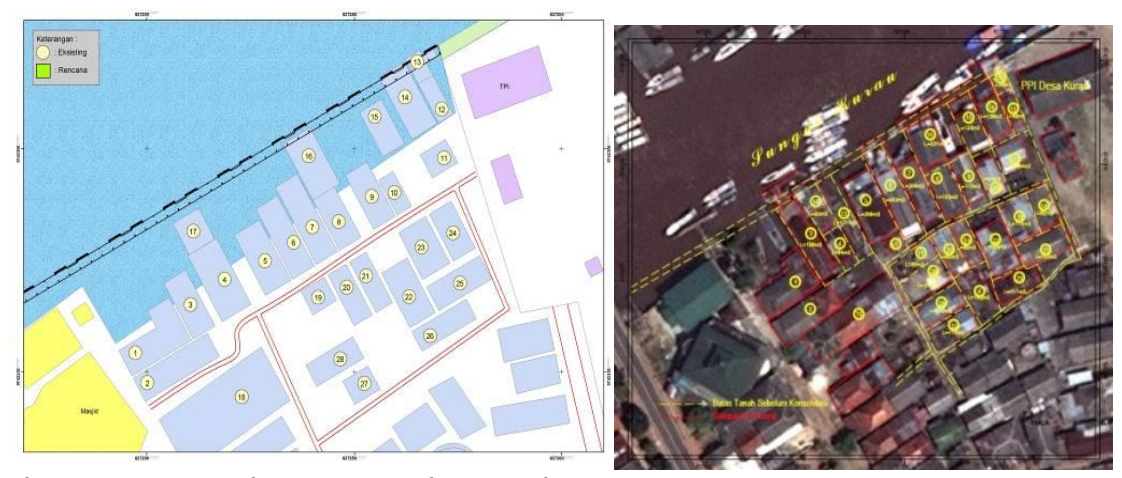

Sumber : Dinas Pekerjaan Umum Kabupaten Bangka Tengah

GAMBAR 2.

KONDISI EXISTING TANAH DAN BANGUNAN KLASTER 1 DESA KURAU SEBELUM KONSOLIDASI TANAH 
JPWK 12 (1)Yurmansah Evaluałi Proses Konsolidasi Tanah Kawasan Permukiman Kumuh Bantaran Sungai Kurau Klaster 1 Desa Kurau Berdasarkan Persepsi Masyarakat

\section{KAJIAN LITERATUR}

\section{Pengertian Evaluasi}

Evaluasi adalah proses penilaian pencapaian tujuan dan pengungkapan masalah kinerja program untuk memberikan umpan balik bagi peningkatan kualitas kinerja program tersebut (Soetomo dkk, 2006). Rossi (1985) memaparkan penelitian evaluasi adalah sistematis prosedur penelitian sosial dalam menilai konseptualisasi dan desain, implementasi dan utilitas program intervensi sosial. dengan kata lain, evaluasi adalah penelitian melibatkan penggunaan metodologi penelitian sosial untuk menilai dan meningkatkan perencanaan, pemantauan, efektivitas, dan efisiensi program kesehatan, pendidikan, kesejahteraan, dan pelayanan manusia lainnya. Tujuan evaluasi menurut Dwijowijoto (2003) adalah untuk menilai sejauh mana keefektifan kebijakan publik guna dipertanggungjawabkan kepada konstituennya. Evaluasi bertujuan untuk mencari kekurangan dan menutup kekurangan (Dwijowijoto, 2003). Sedangkan menurut Soetomo (2006) tujuan evaluasi program yaitu untuk mendapatkan informasi untuk meningkatkan efisiensi dan efektivitas serta untuk memberikan masukan dalam penyempurnaan rencana kegiatan di masa mendatang.

Konsolidasi tanah adalah metode dimana kepemilikan plot tersebar dan tidak teratur tanah pertanian dikumpulkan, jalan dan infrastruktur utama yang dibangun, dan tanah ini kemudian dibagi lagi menjadi plot perkotaan. Setiap pemilik tanah harus menyumbangkan sebagian dari mereka sebelumnya memegang tanah (biasanya sekitar 30\% dari total) untuk memberikan ruang untuk jalan, taman dan ruang publik lainnya, dan untuk tanah cadangan (Sorensen, 2000), metode ini lebih murah dan lebih efisien daripada mengumpulkan tanah di bawah kepemilikan tunggal (Konursay, 2004). Daya tarik untuk perencanaan pemerintah adalah bahwa proyek menyediakan tanah untuk fasilitas umum, dan membangun infrastruktur perkotaan dibutuhkan sehingga dapat mendukung pembangunan perkotaan yang berkelanjutan (UN-Habitat, 2012). Nishiyama (1986) dalam Sorensen (2000) menyatakan bahwa metode ini telah digunakan secara luas, dan dalam berbagai luar biasa dari keadaan, untuk ekspansi perkotaan terutama ke daerah pertanian, tetapi juga untuk pembangunan kembali pusat kota, bangunan kota baru, proyek-proyek perumahan rakyat, kereta api dan pembangunan angkutan massal, dan lain-lain.

Evaluasi proses konsolidasi tanah adalah proses penilaian yang bertujuan mengumpulkan, menganalisis, dan menafsirkan informasi tentang perlunya, pelaksanaan, dan efektivitas dan efisiensi intervensi proses konsolidasi sehingga dapat memberikan umpan balik pada peningkatan kinerja konsolidasi tanah guna peningkatan kinerja program untuk memperbaiki dan meningkatkan kondisi sosial dan kehidupan masyarakat.

\section{Proses konsolidasi lahan}

Konsolidasi tanah menggunakan proses realokasi untuk pembangunan perkotaan dalam bahasa inggris biasanya disebut Land Readjustment (LR). Tahapan yang umum dilakukan dalam konsolidasi tanah (UN-Habitat (2013), Wang (2014), Sorensen (2000) meliputildentifikasi daerah proyek, negosiasi dengan pemilik tanah, membuat peta/merakit tanah (ukuran, bentuk, lokasi), menyediakan tanah untuk ruang publik/infrastruktur dan desain ulang, Membuat rencana/Merealokasikan sisa (massa redistribusi) dan mendesain ulang semua paket, Menghitung kontribusi: ukuran / nilai (valuasi massa / penilaian individual), Pemerintahan (tindakan kolektif / mobilisasi sosial), Perencanaan yang terhubungan dengan ruang/rencana fisik lokal ditambah desain di skala besar. Sedangkan dalam penelitian ini proses konsolidasi tanah yang dilaksanakan evaluasi berdasarkan rangkuman beberapa sumber (UN-Habitat 
Yurmansah | Evaluasi Proses Konsolidasi Tanah Kawasan Permukiman Kumuh Bantaran Sungai Kurau Klaster 1 Desa Kurau Berdasarkan Persepsi Masyarakat

JPWK 12 (1)

(2013), Doebele (1982), Wang (2014), Sorensen (2000), BPN RI (1996)) meliputi sosialisasi, penjajakan kesepakatan, identifikasi subjek dan objek, pengukuran dan pemetaan, pembuatan master plan/block plan, pembuatan desain konsolidasi tanah (distribusi ukuran dan letak), musyawarah tentang rencana penetapan kapling baru dan skema pembiayaan, staking out/realokasi dan sertifikasi.

\section{Kawasan Kumuh}

kampung kumuh atau permukiman kumuh didefinisikan sebagai bentuk hunian tidak berstruktur, kualitas perumahan yang buruk, tidak berpola dengan letak rumah dan jalanjalannya tidak beraturan, tidak tersedia fasilitas umum, prasarana dan sarana permukiman tidak mendukung kondisi lingkungan yang terus menurun. (Yudhohusodo (1991), Rabekka dalam Sobirin (2001), UN-Habitat (2008)). Penanganan terhadap permukiman kumuh (slum), pada umumnya mencakup tiga aspek (Kuswartojo, 2010) yaitu : pertama kondisi fisiknya, kedua kondisi sosial ekonomi budaya komunitas yang bermukim di permukiman tersebut, dan ketiga dampak oleh kedua kondisi tersebut

\section{PROSES KONSOLIDASI TANAH KAWASAN PERMUKIMAN KUMUH BANTARAN SUNGAI KLASTER 1 DESA KURAU}

Konsolidasi tanah kawasan permukiman kumuh bantaran sungai kurau Klaster 1 RT 01 Desa Kurau merupakan pilot project upaya yang dilakukan pemerintah Kabupaten Bangka Tengah untuk merevitalisasi kawasan Desa Kurau. Kawasan Desa Kurau merupakan kawasan yang memiliki banyak potensi yang dikembangkan karena memiliki ciri khas sebagai daerah pesisir (DPU, 2012), Penyusunan Masterplan Revitalisasi Penataan Kawasan Desa Kurau Kecamatan Koba Kabupaten Bangka Tengah merupakan salah satu upaya yang dilakukan untuk mengendalikan dan mengembangkan kawasan sehingga Kawasan Kurau Kecamatan Koba Kabupaten Bangka Tengah ini mampu menjadi salah satu daya tarik dan tujuan wisata di Kabupaten Bangka Tengah (DPU (2012) dan Basri (2014)). Luas kawasan konsolidasi tanah klaster 1 ini 0,39 Ha. Dengan luas kawasan konsolidasi tanah yang kecil dan skala lingkungan, perencanaan tingkat mikro di skala lingkungan rencana konsolidasi tanah yang digunakan untuk membuat ketentuan untuk layanan infrastruktur tingkat mikro seperti akses jalan, air bersih dan jaringan saluran pembuangan dan fasilitas umum lainnya (Mittal, 2014)

\section{Penjajakan kesepakatan}

Penjajakan Kesepakatan dengan tujuan untuk menjaring kesediaan masyarakat untuk dilaksanakan penataan dengan konsolidasi tanah terlebih dahulu mempertimbangkan pendapat masyarakat dimana opsi yang ditawarkan berupa pindah dengan kata lain relokasi atau tetap tinggal sehingga dilaksanakan konsolidasi tanah, masyarakat memilih untuk tetap tinggal atau dilaksanakan konsolidasi tanah dalam rangka penataan kawasan permukiman nelayan kumuh di Desa Kurau dengan mempertimbangkan beberapa hal diantaranya aksesibilitas, kenyamanan serta kondisi sarana dan prasarana (Bani \& ragil, 2013) dan masyarakat tidak mau terlalu jauh dari pinggiran sungai agar mereka mudah untuk mengawasi keamanan kapal yang dimilikinya dan memudahkan akses mereka melaut (Basri,2014).

\section{Penyusunan Master Plan/Site Plan}

Masterplan konsolidasi tanah telah disusun pada tahun 2012, namun sampai dengan tahun 2014 telah mengalami dua kali perubahan. Tahun 2012, jumlah rumah yang terkena penataan atau konsolidasi tanah sebanyak 23 rumah. Pembagian kavling tanah dilaksanakan setelah pengurangan untuk infrastruktur dan sempadan sungai dengan mempertimbangkan luas kepemilikan rumah/bangunan tanpa mempertimbangkan kepemilikan tanah sehingga 
JPWK 12 (1)Yurmansah Evaluałi Proses Konsolidasi Tanah Kawasan Permukiman Kumuh Bantaran Sungai Kurau Klaster 1 Desa Kurau Berdasarkan Persepsi Masyarakat

masyarakat yang tidak memiliki rumah/bangunan dalam lokasi tidak diikutsertakan karena tidak memiliki bukti akan hak kepemilikan tanah. Setiap rumah tangga memperoleh luas tanah yang berbeda sesuai dengan ukuran sebelumnya, ada yang mendapatkan $140 \mathrm{m2}, 105 \mathrm{m2}, 70$ $\mathrm{m} 2$, dan $63 \mathrm{m2}$. Pembagian tersebut didasarkan pada jumlah luas rumah eksisting di mana ukuran tanah tersebut mendekati ukuran rumah yang direncanakan (DPU, 2012). Pada Tahun 2013, terjadi perubahan Masterplan/Siteplan dimana peserta konsolidasi tanah masing-masing memperoleh luas tanah sebesar @ 75 m2 dengan ukuran 6x12,5 meter dengan pembangunan rumah warga ditawarkan rumah prototif tipe 41,25 dengan pengembangan rumah dapat dilaksanakan secara vertikal/bertingkat dan atas persetujuan tim teknis. Perubahan kedua terjadi pada trimester terakhir 2014 pada saat akan dilaksanakan proses sertifikasi yang disebabkan 2 orang warga yang mengaku memiliki tanah kosong, sehingga 2 lokasi yang peruntukan untuk Ruang Terbuka diperuntukan kembali untuk kapling tanah warga. Dari total luas tanah warga sebesar $3.611 \mathrm{M} 2$, dilakukan pengurangan yang dipergunakan untuk pembangunan sarana dan prasarana umum dan lingkungan seluas $1.736 \mathrm{M} 2(48,08 \%)$ dan tidak terdapat tanah cadangan untuk biaya pemulihan infrastruktur dan perumahan.

TABEL I.

DISTRIBUSI/PEMBAGIAN UKURAN KAPLING TANAH KLASTER 1

\begin{tabular}{|c|c|c|c|c|c|c|}
\hline \multirow{3}{*}{ No } & \multirow{3}{*}{ Nama Peserta } & \multirow{3}{*}{ No. Kavling Tanah } & \multicolumn{2}{|c|}{ Luas Tanah Masyarakat } & \multirow{2}{*}{\multicolumn{2}{|c|}{ Perubahan Luas Tanah }} \\
\hline & & & \multirow{2}{*}{$\begin{array}{c}\text { Sebelum } \\
\text { (M2) }\end{array}$} & \multirow{2}{*}{$\begin{array}{c}\text { Sesudah } \\
\text { (M2) }\end{array}$} & & \\
\hline & & & & & (M2) & $(\%)$ \\
\hline 1 & Acok & 14 & 138,00 & 75,00 & $(63,00)$ & $(45,65)$ \\
\hline 2 & Akbar & 17 & 83,00 & 75,00 & $(8,00)$ & $(9,64)$ \\
\hline 3 & Alimudin & 7 & 208,00 & 75,00 & $(133,00)$ & $(63,94)$ \\
\hline 4 & Aliyas & 10 & 93,00 & 75,00 & $(18,00)$ & $(19,35)$ \\
\hline 5 & Ambo Sakka & 24 & 82,00 & 75,00 & $(7,00)$ & $(8,54)$ \\
\hline 6 & Baharudin & 8 & 203,00 & 75,00 & $(128,00)$ & $(63,05)$ \\
\hline 7 & Bakri & 26 & 111,00 & 75,00 & $(36,00)$ & $(32,43)$ \\
\hline 8 & Barayah & 19 & 85,00 & 75,00 & $(10,00)$ & $(11,76)$ \\
\hline 9 & Becek & 11 & 184,00 & 75,00 & $(109,00)$ & $(59,24)$ \\
\hline 10 & Daling & 21 & 80,00 & 75,00 & $(5,00)$ & $(6,25)$ \\
\hline 11 & H. Akbar & 5 & 309,00 & 75,00 & $(234,00)$ & $(75,73)$ \\
\hline 12 & Hamid & 20 & 80,00 & 75,00 & $(5,00)$ & $(6,25)$ \\
\hline 13 & Hane & 6 & 203,00 & 75,00 & $(128,00)$ & $(63,05)$ \\
\hline 14 & Jumrah & 28 & 110,00 & 75,00 & $(35,00)$ & $(31,82)$ \\
\hline \multirow{2}{*}{15} & \multirow{2}{*}{ Junaida } & 4 & 64,00 & \multirow{2}{*}{75,00} & \multirow{2}{*}{$(131,00)$} & \multirow{2}{*}{$(63,59)$} \\
\hline & & 4 & 142,00 & & & \\
\hline 16 & Juraida & 23 & 114,00 & 75,00 & $(39,00)$ & $(34,21)$ \\
\hline 17 & Khoirudin & 9 & 110,00 & 75,00 & $(35,00)$ & $(31,82)$ \\
\hline 18 & Masdar & 3 & 199,00 & 75,00 & $(124,00)$ & $(62,31)$ \\
\hline 19 & Matnong & 15 & 123,00 & 75,00 & $(48,00)$ & $(39,02)$ \\
\hline \multirow{2}{*}{20} & \multirow{2}{*}{ Mirwana } & 13 & 29,00 & \multirow{2}{*}{75,00} & \multirow{2}{*}{$(85,00)$} & \multirow{2}{*}{$(53,13)$} \\
\hline & & 13 & 131,00 & & & \\
\hline 21 & Malyati & 27 & 114,00 & 75,00 & $(39,00)$ & $(34,21)$ \\
\hline 22 & Saharudin & 29 & 130,00 & 75,00 & $(55,00)$ & $(42,31)$ \\
\hline 23 & Sambak & 16 & 231,00 & 75,00 & $(156,00)$ & $(67,53)$ \\
\hline 24 & Sapewali & 22 & 195,00 & 75,00 & $(120,00)$ & $(61,54)$ \\
\hline \multirow[t]{2}{*}{25} & Sudirman & 12 & 60,00 & 75,00 & 15,00 & 25,00 \\
\hline & \multicolumn{2}{|l|}{ JUMLAH } & $3.611,00$ & 1.875 & $(1.736,00)$ & $(48,08)$ \\
\hline
\end{tabular}


Yurmansah | Evaluasi Proses Konsolidasi Tanah Kawasan Permukiman Kumuh Bantaran Sungai Kurau Klaster 1 Desa Kurau Berdasarkan Persepsi Masyarakat

JPWK 12 (1)

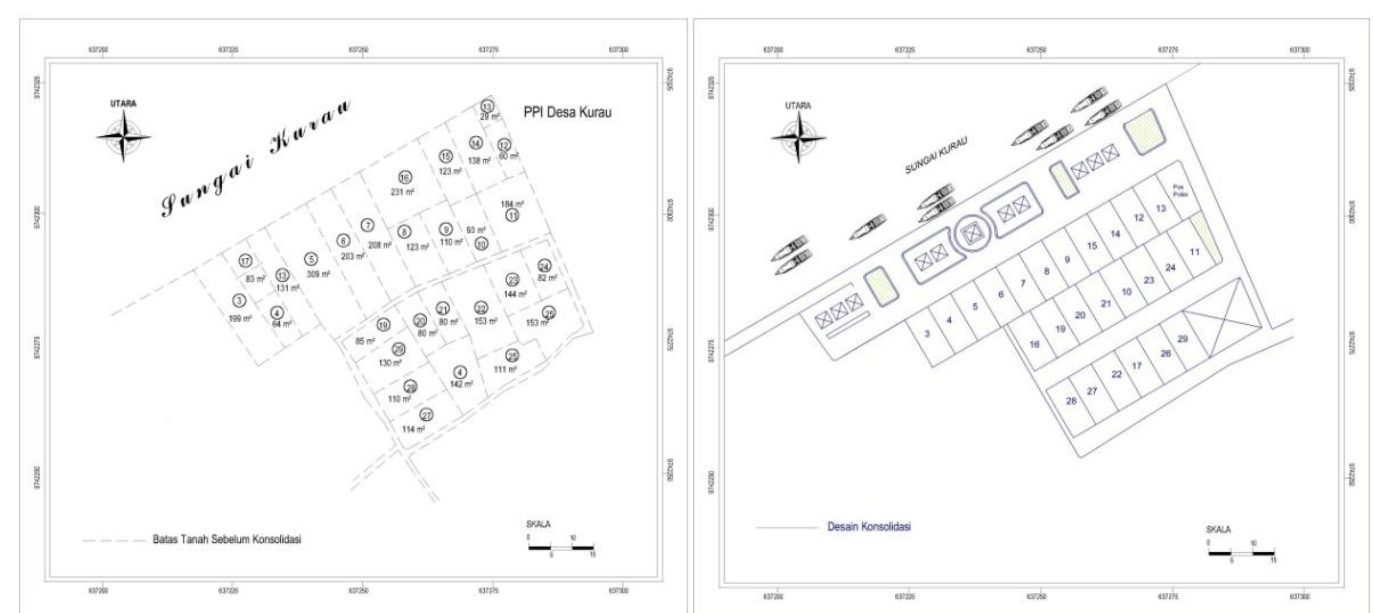

Sumber: Dinas Pekerjaan Umum dan BPN Kabupaten Bangka Tengah

GAMBAR 3.

SITE PLAN DAN KONDISI KAPLING TANAH KLASTER 1 DESA KURAU SEBELUM DAB SETELAH KONSOLIDASI TANAH

\section{Sosialisasi dan Musyawarah}

Sosialisasi dan musyawarah rencana konsolidasi tanah dilaksanakan secara bersamaan setelah masyarakat memilih untuk dilakukan penataan dengan konsolidasi tanah. Pada tahun 2012, Sosialisasi dan musyawarah konsolidasi tanah bantaran sungai Klaster 1 Desa Kurau dilaksanakan pada hari Jumat tanggal 2 November 2012 dihadiri oleh H. Erzaldi Rosman Djohan, SE. MM selaku Bupati Bangka Tengah (DPU, 2012). Pada tahun 2014, sosialisasi dan musyawarah dengan masyarakat difokuskan pada persiapan pelaksanaan yang meliputi pengukuran untuk pembuatan sertifikasi, pemantapan skema pembiayaan dan pelaksanaan realokasi berupa realokasi tanah hasil konsolidasi tanah, penataan dan pembangunan rumah.

TABEL II.

HASIL KESEPAKATAN PARA PIHAK DALAM PROSES KONSOLIDASI TANAH KAWASAN PERMUKIMAN BANTARAN SUNGAI KLASTER 1 DESA KURAU

\begin{tabular}{|c|c|}
\hline & HAK DAN KEWAJIBAN \\
\hline Masyarakat & $\begin{array}{l}\text { 1. Meneriman Bantuan Maks Rp. } 60.000 .000,- \text {, terdiri dari : } \\
\text { 2. Pinjaman Bank maks Rp. } 50.000 .000 \text {, margin } 4 \% \\
\text { 3. Bantuan Cuma-Cuma Rp. } 10.000 .000 \\
\text { 4. Menerima sertifikat kepemilikan tanah secara gratis } \\
\text { 5. Setuju dengan Desain rumah Pengembangan atas persetujuan tim teknis } \\
\text { 6. Membongkar rumah dan membangun kembali secara mandiri, gotong royong dan } \\
\text { semaksimal mungkin memanfaatkan material hasil bongkaran rumah sebelumnya } \\
\text { 7. Melaksanakan pembangunan paling lambat pada saat Kredit dikucurkan dari Bank }\end{array}$ \\
\hline Pemerintah & $\begin{array}{l}\text { 1. Menyiapkan bantuan dana @ Rp. } 10.000 .000,- \text { /peserta dari CSR/ APBD Kabupaten/ APBD } \\
\text { Provinsi/APBN atau sumber lainnya yang sah; } \\
\text { 2. Menyiapkan anggaran/dana talangan pinjaman @ Rp. } 50.000 .000 \text {, yang berasal dari APBD } \\
\text { Bangka Tengah untuk diserahkan ke Bank yang ditunjuk oleh Pemerintah Kabupaten } \\
\text { Bangka Tengah; } \\
\text { 3. Pemberian sertifikat kepemilikan tanah secara gratis } \\
\text { 4. Memberikan bantuan teknis perencanaan dan pendampingan secara mandiri } \\
\text { 5. Pembangunan sarana dan prasarana umum (PSU) yang didanai (APBD)/(APBN)/CSR }\end{array}$ \\
\hline
\end{tabular}

Sumber : Dinas Pekerjaan Umum Kabupaten Bangka Tengah 
JPWK 12 (1)Yurmansah Evaluałi Proses Konsolidasi Tanah Kawasan Permukiman Kumuh Bantaran Sungai Kurau Klaster 1 Desa Kurau Berdasarkan Persepsi Masyarakat

\section{Sertifikasi dan Realokasi/Pemindahan Desain Ke Lapangan}

Sertifikasi tanah hasil konsolidasi tahan telah diterbitkan pada oktober 2014 dengan anggaran bersumber dari APBD-P Kabupaten Bangka Tengah Tahun Anggaran 2014. Penyerahan sertifikat tanah diberikan kepada 5 peserta tahap pertama, namun sertifikat tanah peserta konsolidasi tanah yang lainnya sebanyak 20 kavling tanah belum diserahkan karena pelaksanaan penataan yang meliputi pembongkaran dan pembangunn kembali rumah warga belum dilaksanakan. Pelaksanaan realokasi, pembongkaran dan pembangunan kembali rumah baru dilaksanakan sebanyak 5 (lima) rumah warga dengan type 41,25 pada akhir Tahun 2014 dengan spesifikasi rumah panggung dengan pondasi beton bertulang, dinding kayu/papan dan calsiboard/GRC dan atap asbes.

\section{Dukungan Pemerintah}

Pelaksanaan Konsolidasi Tanah di Klaster 1 RT 01 Desa Kurau ini mendapat dukungan sangat tinggi dari Pemerintah Daerah khususnya Drs. H. Erzaldi Rosman, MM sebagai Bupati Bangka Tengah yang sangat menginginkan tidak ada lagi rumah yang tidak layak huni dan pemukiman kumuh di wilayah yang menjadi kewenangannya dan Ir. H. Ibnu Saleh, MM Sebagai Sekda Kabupaten Bangka Tengah selaku koordinator dan pelaksana pembangunan mengupayakan ketersediaan anggaran agar strategi mengurangi pemukiman kumuh secara mandiri dan swakelola masyarakat ini dpt berjalan (Basri, 2014). Selain itu dukungan pihak eksekutif dalam hal ini DPRD Kabupaten Bangka Tengah (Basri, 2014) dalam upaya menyiapkan perangkat peraturan pendukung pelaksanaan antara lain Peraturan Daerah guna penyiapan dana talangan pinjaman berbunga rendah dan Upaya Anggota DPRD yang berasal dari Desa Kurau sendiri dalam memusyawarahkan dan menjelaskan kembali program kepada masyarakat

TABEL III.

PEMBIAYAAN PEMBANGUNAN RUMAH KEMBALI YANG TELAH DILAKSANAKAN

\begin{tabular}{|c|c|c|c|c|c|}
\hline \multirow[b]{2}{*}{ NO } & \multirow[b]{2}{*}{ NAMA } & \multicolumn{3}{|c|}{ PEMBIAYAAN } & \multirow[b]{2}{*}{ KET. } \\
\hline & & Bantuan CSR & $\begin{array}{l}\text { Kredit Lunak PT. } \\
\text { BPR Syariah } \\
\text { Bangka Belitung } \\
\text { (Margin 4\%) }\end{array}$ & Bantuan Lainnya & \\
\hline 1 & Masdar & Rp 10.000 .000 & Rp 30.000 .000 & Asbes 20 Kpg, Pasir, dan Kerikil & \\
\hline 2 & Junaida & Rp 25.000 .000 & $\mathrm{Rp}$ & - & $\begin{array}{c}\text { Bantuan Rumah } \\
\text { Type } 21 \\
\end{array}$ \\
\hline 3 & H. Akbar & Rp 10.000 .000 & Rp 50.000 .000 & Asbes 20 Kpg, Pasir, dan Kerikil & \\
\hline 4 & Hane & Rp 10.000 .000 & Rp 50.000 .000 & Asbes 20 Kpg, Pasir, dan Kerikil & \\
\hline \multirow[t]{2}{*}{5} & Alimudin & Rp 10.000 .000 & Rp 50.000 .000 & Asbes 20 Kpg, Pasir, dan Kerikil & \\
\hline & JUMLAH & Rp 65.000 .000 & Rp $\quad 180.000 .000$ & & \\
\hline
\end{tabular}

Sumber : Analisis Peneliti, 2015

\section{ANALISIS TINGKAT KEBERHASILAN PROSES KONSOLIDASI TANAH}

Berdasarkan hasil analisis, bahwa terjawab pertanyaan penelitian dimana tingkat keberhasilan proses konsolidasi tanah permukiman kumuh bantaran sungai Klaster 1 RT 01 Desa Kurau adalah berhasil yang dilihat dari 4 (empat) kriteria evaluasi yaitu efektivitas, efisiensi, kesetaraan/keadilan dan Responsivitas. Berdasarkan hasil analisis yang terdapat pada tabel VI, dan berdasarkan tabel kriteria tingkat keberhasilan pada tabel $\mathrm{V}$, menurut persepsi masyarakat 
Yurmansah | Evaluasi Proses Konsolidasi Tanah Kawasan Permukiman Kumuh Bantaran Sungai Kurau Klaster 1 Desa Kurau Berdasarkan Persepsi Masyarakat

JPWK 12 (1)

bahwa hal ini didukung oleh berhasilnya setiap tahapan proses konsolidasi tanah dan didukung oleh faktor dominan berurutan yaitu setara adil (skor 638), efektif (skor 631), responsif (skor 617) dan efisien (579).

Proses konsolidasi tanah dapat berjalan setara/adil dengan skor 638, hal ini menyatakan berdasarkan persepsi masyarakat bahwa biaya dan manfaat dari proses konsolidasi ini memiliki kecenderungan dapat didistribusikan dengan merata/adil kepada peserta konsolidasi. Dari 10 (sepuluh) tahapan konsolidasi tanah yang dievaluasi, 8 (delapan) tahapan (80\%) dapat dilaksanakan secara adil/setara. Proses konsolidasi tanah berjalan dengan efektif dengan skor 631, hal ini menyatakan berdasarkan persepsi masyarakat bahwa tahapan proses konsolidasi tanah yang dilaksanakan memiliki kecenderungan dapat mencapai hasil yang diharapkan sesuai dengan tujuan tahapan konsolidasi tanah. Dari 10 (sepuluh) tahapan konsolidasi tanah yang dievaluasi, 9 (sembilan) tahapan (90\%) dapat dilaksanakan secara efektif. Proses konsolidasi tanah secara umum dapat berjalan responsif dengan skor 617, hal ini menyatakan berdasarkan persepsi masyarakat bahwa tahapan proses konsolidasi tanah memiliki kecenderungan dapat memuaskan kebutuhan, preferensi atau nilai dari peserta konsolidasi tanah. Dari 10 (sepuluh) tahapan konsolidasi tanah yang dievaluasi, 7 (tujuh) tahapan (70\%) dapat dilaksanakan secara responsif. Dalam proses konsolidasi tanah secara umum berjalan efisien dengan skor 579, hal ini menyatakan berdasarkan persepsi masyarakat memiliki kecenderungan bahwa usaha yang diperlukan untuk mencapai tujuan dapat berhasil, namun nilai skor efisien ini hampir memiliki kecenderungan mendekati kurang efisien (interval kurang efisien $>402,5$ dan $<575$ ) dan dari 10 tahapan yang dievaluasi, hanya 4 (empat) tahapan (40\%) yang dapat dilaksanakan secara efisien.

TABEL IV.

KRITERIA PENCAPAIAN TINGKAT KEBERHASILAN

\begin{tabular}{|c|c|c|c|}
\hline $\begin{array}{c}\text { Capaian Tingkat Keberhasilan } \\
\text { Tiap Tahapan Konsolidasi } \\
\text { Tanah }\end{array}$ & $\begin{array}{c}\text { Jumlah Skor Tingkat } \\
\text { Keberhasilan Tiap } \\
\text { Tahapan Konsolidasi } \\
\text { Tanah } \\
\end{array}$ & $\begin{array}{c}\text { Jumlah Skor Tingkat } \\
\text { Keberhasilan Kriteria } \\
\text { Evaluasi Konsolidasi } \\
\text { Tanah } \\
\end{array}$ & $\begin{array}{c}\text { Jumlah Skor Tingkat } \\
\text { Keberhasilan Proses } \\
\text { Konsolidasi Tanah }\end{array}$ \\
\hline Sangat Tidak Berhasil & $\geq 92$ dan $\leq 161$ & $\geq 230$ dan $\leq 402,5$ & $\geq 920$ dan $\leq 1.610$ \\
\hline Kurang Berhasil & $>161$ dan $\leq 230$ & $>402,5$ dan $\leq 575$ & $>1610$ dan $\leq 2.300$ \\
\hline Berhasil & $>230$ dan $\leq 299$ & $>575$ dan $\leq 747,5$ & $>2300$ dan $\leq 2.990$ \\
\hline Sangat Berhasil & $>299$ dan $\leq 368$ & $>747,5$ dan $\leq 920$ & $>2990$ dan $\leq 3.680$ \\
\hline $\begin{array}{l}\text { Keterangan } \\
\text { - } \text { BTT (Bobot Tertinggi) }=4 \\
\text { - } \text { BTR }(\text { Bobot Terendah })=1 \\
\text { - } \mathrm{R}(\text { jumlah Responden })=23 \\
\text { - JKE }(\text { Jumlah Kriteria } \\
\text { Evaluasi }=4 \\
\text { - } \text { V }(\text { Jumlah Variabel })=10 \\
\text { - JK }(\text { Jumlah Kelas })=4\end{array}$ & $\begin{array}{l}\text { Skor Tertinggi (STT) } \\
\quad=\text { BTT } \times \text { RxJKE } \\
=4 \times 23 \times 4=368 \\
\text { Skor Terendah (NTR) } \\
\quad=\text { BTRxRxJKE } \\
\quad=1 \times 23 \times 1=92 \\
\text { Interval }=(\mathrm{STT}-\mathrm{STR}) / \mathrm{JK} \\
=(368-92) / 4=69\end{array}$ & $\begin{array}{l}\text { Skor Tertinggi (STT) } \\
\quad=\mathrm{BTT} \times \mathrm{R} \times \mathrm{V} \\
\quad=4 \times 23 \times 10=920 \\
\text { Skor Terendah }(\mathrm{NTR}) \\
\quad=\mathrm{BTR} \times \mathrm{RxV} \\
=1 \times 23 \times 10=230 \\
\text { Interval }=(\mathrm{STT}-\mathrm{STR}) / \mathrm{JK} \\
=(920-230) / 4=172,5\end{array}$ & $\begin{array}{l}\text { Skor Tertinggi (STT) } \\
\quad=\text { BTTxRxJxJKEXV } \\
\quad=4 \times 23 \times 4 \times 10 \\
=3.680 \\
\text { Skor Terendah (NTR) } \\
\quad=\text { BTRxRxJKExV } \\
\quad=1 \times 23 \times 4 \times 10 \\
=920 \\
\text { Interval }=(\mathrm{STT}-\mathrm{STR}) / \mathrm{JK} \\
=(920-230) / 4=172,5\end{array}$ \\
\hline
\end{tabular}

Sumber : Analisis Penulis, 2015 
JPWK 12 (1)Yurmansah Evaluałi Proses Konsolidasi Tanah Kawasan Permukiman Kumuh Bantaran Sungai Kurau Klaster 1 Desa Kurau Berdasarkan Persepsi Masyarakat

TABEL V.

KRITERIA PENCAPAIAN TIAP INDIKATOR TAHAPAN

\begin{tabular}{|c|c|c|}
\hline $\begin{array}{l}\text { Capaian Tingkat Keberhasilan Tiap } \\
\text { Indikator Tahapan Konsolidasi Tanah }\end{array}$ & Jumlah Skor & Keterangan \\
\hline $\begin{array}{l}\text { Sangat Tidak Efektif/Efisien/ } \\
\text { adil/Responsif }\end{array}$ & $\geq 23$ dan $\leq 40,3$ & \multirow{4}{*}{$\begin{array}{l}\text { - } \mathrm{BTT}(\text { Bobot Tertinggi })=4 \\
\text { - } \mathrm{BTR}(\text { Bobot Terendah })=1 \\
\text { - } \mathrm{R}(\text { jumlah Responden })=23 \\
\text { - JK }(\text { Jumlah Kelas })=4 \\
\text { - Skor tertinggi }=\text { BTT } \times \mathrm{R}=4 \times 23=92 \\
\text { - Skor Terendah }=\text { BTR } \times \mathrm{R}=1 \times 23=23 \\
\text { - Interval }=(92-23) / 4=17,25\end{array}$} \\
\hline Kurang Efektif/Efisien/ adil/Responsif & $>40,3$ dan $\leq 57,5$ & \\
\hline Efektif/Efisien/ adil/Responsif & $>57,5$ dan $\leq 74,8$ & \\
\hline Sangat Efektif/Efisien/ adil/Responsif & $>74,8$ dan $\leq 92$ & \\
\hline
\end{tabular}

Sumber : Analisis Penulis, 2015

TABEL VI. JUMLAH SKOR DAN TINGKAT PENCAPAIAN EVALUASI

\begin{tabular}{|c|c|c|c|c|c|c|c|c|c|c|c|}
\hline \multirow{3}{*}{ NO } & \multirow{3}{*}{ SUB VARIABEL } & \multicolumn{8}{|c|}{ KRITERIA EVALUASI } & \multirow{3}{*}{$\begin{array}{l}\text { Jum- } \\
\text { lah } \\
\text { Skor }\end{array}$} & \multirow{3}{*}{$\begin{array}{l}\text { Penca- } \\
\text { paian } \\
\text { Indikator }\end{array}$} \\
\hline & & \multicolumn{2}{|c|}{ Efektifitas } & \multicolumn{2}{|c|}{ Efisiensi } & \multicolumn{2}{|c|}{$\begin{array}{c}\text { Kesetaraan/ } \\
\text { Keadilan }\end{array}$} & \multicolumn{2}{|c|}{ Responsivitas } & & \\
\hline & & Skor & $\begin{array}{c}\text { Penca- } \\
\text { paian }\end{array}$ & Skor & $\begin{array}{l}\text { Penca- } \\
\text { paian }\end{array}$ & Skor & $\begin{array}{l}\text { Penca- } \\
\text { paian }\end{array}$ & Skor & $\begin{array}{l}\text { Penca- } \\
\text { paian }\end{array}$ & & \\
\hline 1 & Sosialisasi & 61 & Efektif & 61 & Efisien & 54 & $\begin{array}{c}\text { Kurang } \\
\text { Setara/ } \\
\text { Adil }\end{array}$ & 66 & $\begin{array}{l}\text { Res- } \\
\text { ponsif }\end{array}$ & 242 & Berhasil \\
\hline 2 & $\begin{array}{l}\text { Penjajakan } \\
\text { Kesepakatan }\end{array}$ & 64 & Efektif & 48 & $\begin{array}{l}\text { Kurang } \\
\text { Efisien }\end{array}$ & 68 & $\begin{array}{l}\text { Setara/ } \\
\text { Adil }\end{array}$ & 72 & $\begin{array}{c}\text { Res- } \\
\text { ponsif }\end{array}$ & 252 & Berhasil \\
\hline 3 & $\begin{array}{l}\text { Identifikasi } \\
\text { Subjek/objek }\end{array}$ & 72 & Efektif & 53 & $\begin{array}{l}\text { Kurang } \\
\text { Efisien }\end{array}$ & 79 & $\begin{array}{l}\text { Sangat } \\
\text { Setara/ } \\
\text { Adil }\end{array}$ & 62 & $\begin{array}{l}\text { Res- } \\
\text { ponsif }\end{array}$ & 266 & Berhasil \\
\hline 4 & $\begin{array}{ll}\text { Pengukuran } & \text { dan } \\
\text { pemetaan Awal } & \\
\end{array}$ & 69 & Efektif & 54 & $\begin{array}{l}\text { Kurang } \\
\text { Efisien }\end{array}$ & 73 & $\begin{array}{l}\text { Setara/ } \\
\text { Adil }\end{array}$ & 62 & $\begin{array}{c}\text { Res- } \\
\text { ponsif }\end{array}$ & 258 & Berhasil \\
\hline 5 & $\begin{array}{l}\text { Pembuatan Master } \\
\text { Plan/Block Plan }\end{array}$ & 60 & Efektif & 54 & $\begin{array}{l}\text { Kurang } \\
\text { Efisien }\end{array}$ & 67 & $\begin{array}{l}\text { Setara/ } \\
\text { Adil }\end{array}$ & 63 & $\begin{array}{c}\text { Res- } \\
\text { ponsif }\end{array}$ & 244 & Berhasil \\
\hline 6 & $\begin{array}{l}\text { Pembuatan Desain } \\
\text { Konsolidasi Tanah } \\
\text { (Distribusi/Pembagian } \\
\text { Bentuk dan Ukuran } \\
\text { Kavling) }\end{array}$ & 60 & Efektif & 52 & $\begin{array}{l}\text { Kurang } \\
\text { Efisien }\end{array}$ & 66 & $\begin{array}{l}\text { Setara/ } \\
\text { Adil }\end{array}$ & 54 & $\begin{array}{l}\text { Kuran } \\
\text { g Res- } \\
\text { ponsif }\end{array}$ & 232 & Berhasil \\
\hline 7 & $\begin{array}{l}\text { Pembuatan Desain } \\
\text { Konsolidasi Tanah } \\
\text { (Distribusi/Pembagian } \\
\text { Letak/posisi Kavling) }\end{array}$ & 62 & Efektif & 65 & Efisien & 60 & $\begin{array}{l}\text { Setara/ } \\
\text { Adil }\end{array}$ & 63 & $\begin{array}{c}\text { Respo } \\
\text { nsif }\end{array}$ & 250 & Berhasil \\
\hline 8 & $\begin{array}{l}\text { Musyawarah rencana } \\
\text { penetapan Kapling } \\
\text { Baru (Desain } \\
\text { konsolidasi tanah \& } \\
\text { Skema Pembiayaan) }\end{array}$ & 67 & Efektif & 55 & $\begin{array}{l}\text { Kurang } \\
\text { Efisien }\end{array}$ & 54 & $\begin{array}{c}\text { Kurang } \\
\text { Setara/ } \\
\text { Adil }\end{array}$ & 57 & $\begin{array}{l}\text { Kuran } \\
\text { g Res- } \\
\text { ponsif }\end{array}$ & 233 & Berhasil \\
\hline 9 & $\begin{array}{l}\text { Realokasi/ } \\
\text { pemindahan Desain } \\
\text { Konsolidasi Tanah ke } \\
\text { Lapangan }\end{array}$ & 60 & Efektif & 65 & Efisien & 59 & $\begin{array}{l}\text { Setara/ } \\
\text { Adil }\end{array}$ & 51 & $\begin{array}{l}\text { Kuran } \\
\text { g Res- } \\
\text { ponsif }\end{array}$ & 235 & Berhasil \\
\hline 10 & Sertifikasi & 56 & $\begin{array}{l}\text { Kurang } \\
\text { Efektif }\end{array}$ & 72 & Efisien & 58 & $\begin{array}{l}\text { Setara/ } \\
\text { Adil }\end{array}$ & 67 & $\begin{array}{c}\text { Res- } \\
\text { ponsif }\end{array}$ & 253 & Berhasil \\
\hline & JUMLAH SKOR & 631 & & 579 & & 638 & & 617 & & 2465 & \\
\hline & $\begin{array}{l}\text { TINGKAT } \\
\text { KEBERHASILAN }\end{array}$ & \multicolumn{2}{|c|}{ Berhasil } & \multicolumn{2}{|c|}{ Berhasil } & \multicolumn{2}{|c|}{ Berhasil } & \multicolumn{2}{|c|}{ Berhasil } & \multicolumn{2}{|c|}{ Berhasil } \\
\hline
\end{tabular}


Yurmansah | Evaluasi Proses Konsolidasi Tanah Kawasan Permukiman Kumuh Bantaran Sungai Kurau Klaster 1 Desa Kurau Berdasarkan Persepsi Masyarakat

JPWK 12 (1)

Sumber: Analisis Peneliti, 2015

\section{Faktor-Faktor Yang Menghambat Penataan/Realokasi Hasil Konsolidasi Tanah}

Mekipun proses konsolidasi tanah kawasan permukiman kumuh bantaran sungai klaster 1 RT 01 Desa Kurau ini cukup berhasilnya, namun ternyata tidak serta merta dapat dilanjutkan atau diimplementasikan di lapangan dimana kesepakatan hasil konsolidasi tanah hanya dapat dilaksanakan sebanyak 5 peserta dari 25 peserta (20\%). Meskipun pelaksanaan secara keseluruhan tahapan proses konsolidasi tanah berjalan efektif dimana tujuan-tujuan tahapantahapan dalam proses konsolidasi itu sendiri sampai dengan kesepakatan dapat tercapai dan berhasil namun efisiensi, keadilan/kesetaraan dan responsivitas masyarakat terhadap tahapantahapan itu sendiri dapat saja menghambat pelaksanaan hasil konsolidasi tanah terutama pada hasil kesepakatan konsolidasi tanah. hal ini dapat dilihat pada konsolidasi tanah kawasan permukiman kumuh bantaran sungai klaster 1 Desa Kurau ini. hal ini disebabkan oleh :

\section{Proses konsesus}

Persetujuan masyarakat dan penerimaan atas hasil konsolidasi tanah serta keikutsertaan masyarakat lebih untuk mendapatkan sertifikat kepemilikan tanah untuk keamanan agar tidak digusur karena mereka mengaku menempati tanah yang bukan milik mereka. Tekanan untuk mencapai konsensus karena itu dapat mengakibatkan hanya dalam penyembunyian hubungan kekuasaan dalam kelompok, bukan partisipasi yang tulus dalam membuat keputusan (Sorensen, 2000) dan Tang et.al. (2012) dalam Wang et.al. (2014) berpendapat, strategi konsolidasi tanah 'top-down telah diberikan prioritas untuk efisiensi administrasi bukan efisiensi usaha. Ketidaktahuan, atau lebih buruk, mengabaikan, kebutuhan dan kecemasan akan menghasilkan resistensi yang menggerogoti efisiensi administrasi atau bahkan melalui demonstrasi sesekali terhadap kebijakan pemerintah, mengganggu stabilitas sosial.

\section{Kesetaraan/Keadilan dalam Distribusi/Pembagian Posisi Kavling}

Berdasarkan hasil penelitian, distribusi/pembagian posisi kavling dapat berhasil dimana dapat berjalan efektif, efisien, setara/adil dan responsif. Meskipun secara keseluruhan distribusi/pembagian posisi kavling dapat berhasil namun terdapat seorang peserta yang protes terhadap hasil distibusi/pembagian letak/posisi kavling tanah karena pergeseran jauh dari letak/posisi tanah semula. seperti yang dinyatakan oleh Viitanen (2002) dalam Yilmaz et.al (2015) bahwa prosedur konsolidasi tanah dibenarkan tidak hanya didasarkan pada biaya yang terlibat dan efisiensi metode tetapi juga berdasarkan perlakuan adil dari pemilik tanah, perbaikan kualitas rencana, tabungan kepada masyarakat, dan manfaat lingkungan. Selain itu peserta konsolidasi tanah cenderung kurang memperhatikan tahapan konsolidasi tanah dan bahkan hanya cenderung ikut-ikutan saja

\section{Efisiensi dan Kesetaraan/Keadilan Distribusi/Pembagian Ukuran Kavling Tanah}

Dalam konsolidasi tanah permukiman kumuh Bantaran Sungai Kurau Klaster 1, Ukuran kavling tanah berkaitan langsung dengan ukuran rumah yang akan dibangun dimana peruntukan kavling tanahnya untuk pembangunan rumah. Pembagian ukuran tanah/kavling berjalan efektif dan adil yaitu dapat disetujui dan masyarakat mengaku adil, namun masyarakat kurang puas karena ukuran tanah yang mereka terima kurang mencukupi sebagaimana telah dibahas sebelumnya. Ukuran ideal area konsolidasi ini sangat penting guna mencapai efektifitas dan efisien konsolidasi tanah dan Pengurangan ukuran tanah yang dilakukan untuk memulihkan infrastruktur teknis dan sosial dan terkait dengan distribusi menjadi dua hal yang dapat menyebabkan penolakan (Turk,2007). 
JPWK 12 (1)Yurmansah Evaluałi Proses Konsolidasi Tanah Kawasan Permukiman Kumuh Bantaran Sungai Kurau Klaster 1 Desa Kurau Berdasarkan Persepsi Masyarakat

\section{Efisiensi dan Kesetaraan/Keadilan Skema Pembiayaan Pemulihan Kembali}

Kesepakatan dalam skema pembiayaan menjadi titik krusial dalam konsolidasi tanah ini, meskipun hasil penelitian menyatakan bahwa skema pembiayaan pembangunan kembali berjalan efektif atau masyarakat dapat menyetujui skema pembiayaan yang disepakati, namun dari segi efisiensi, keadilan/kesetaraan dan responsivitas masih kurang tercapai, hal ini menjadi titik lemah dalam penetapan kesepakatan. Meskipun skema pembiayaan mencukupi untuk membangun rumah sesuai gambar rencana dengan type 41,25, namun masyarakat mengaku kurang setara/adil karena tanggungan pinjaman kredit selama 20 tahun memberatkan.

Kurang efisiennya skema pembiayaan pemulihan yang tersedia disebabkan oleh lima hal. Pertama, tidak tersedianya dana dari hasil konsolidasi tanah yang diperoleh kelebihan tanah yang dapat dijual biaya pembangunan atau dialokasikan ke bank tanah, hal tersebut juga disampaikan Yilmaz et. al (2015). Bank tanah ini menghasilkan dana tambahan untuk memulihkan biaya perkembangan baru dan cadangan kas (Alexander, 2008 dalam Mittal, 2014). Kedua, tidak terlaksananya mekanisme pembangunan secara mandiri oleh masyarakat dengan sistem gotong-royong. Ketiga, Masyarakat mengaku skema pembiayaan diterima tidak mencukupi untuk pembangunan rumah secara vertikal/bertingkat untuk memenuhi kebutuhan luas rumah warga. Keempat, Selain itu masyarakat belum sepenuhnya mengerti tentang mekanisme pinjaman bantuan dari bank sehingga membuat mereka merasa berat membayar selama 20 tahun dan takut akan disita jika terjadi keterlambatan pembayaran 3 sampai 5 bulan. Kelima, adanya keraguan masyarakat dalam melaksanakan pembayaran angsuran pinjaman kredit karena masyarakat mengaku memiliki penghasilan tidak tetap dan tidak menentu sebagai nelayan.

\section{Pengaruh dari luar (Eksternal)}

Pengaruh dari luar berupa kelompok atau pihak luar yang dapat mempengaruhi masyarakat dalam melaksanakan hasil kesepakatan merupakan salah satu faktor yang dapat mengganggu hasil kesepakatan dalam konsolidasi tanah kawasan permukiman bantaran sungai kurau klaster 1 RT 01 Desa Kurau ini. Meskipun awal mulai protes dimulai dari dalam akibat ketidakpuasan peserta dalam distribusi/pembagian letak/posisi kavling, namun hasutan/provokasi dari pihak luar yang dapat mempengaruhi warga menjadi penyebab muncul aksi penolakan secara massal.

\section{Kuantitas dan Kualitas Tenaga Teknis}

Tingginya dukungan dan kepemimpinan yang kuat dari Erzaldi Rosman sebagai Bupati Bangka Tengah dan adanya dukungan Anggota DPRD Kabupaten Bangka Tengah, namun kurangnya manajemen dalam pelaksanaan konsolidasi tanah tersebut dapat menjadi hambatan dalam pelaksanaan konsolidasi tanah tersebut baik kelembagaan yang tidak melibatkan secara langsung BPN pada proses konsolidasi tanah pada Klaster 1 namun hanya terlibat dalam proses sertifikasi saja yang berakibat pada kurangnya kualitas teknis dan kuantitas tenaga teknis. Hal tersebut juga disampaikan Sorensen (2000a) bahwa tuntutan berat konsolidasi tanah pada sumber daya perencanaan, khususnya saat tenaga terampil tampaknya menjadi kelemahan utama dari metode ini. Pra-syarat yang penting untuk sukses konsolidasi tanah setidaknya tiga kondisi yang penting: kebutuhan untuk alat hukum atau kerangka peraturan, menguntungkan pasar Real Estate dan perlu untuk kepemimpinan politik yang kuat dan dukungan-publik (Mittal,2014).

\section{KESIMPULAN}


Yurmansah | Evaluasi Proses Konsolidasi Tanah Kawasan Permukiman Kumuh Bantaran Sungai Kurau Klaster 1 Desa Kurau Berdasarkan Persepsi Masyarakat

JPWK 12 (1)

Berdasarkan hasil analisis terhadap tingkat keberhasilan proses konsolidasi tanah kawasan permukiman kumuh bantaran sungai kurau Klaster 1 Desa Kurau, maka diperoleh beberapa kesimpulan sebagai berikut :

1. Proses konsolidasi tanah permukiman kumuh bantaran sungai kurau Klaster 1 Desa Kurau berhasil dengan didukung faktor dominan secara berurutan dimana berjalan adil/setara (skor 638), efektif (skor 631), responsif (skor 617) dan efisien (skor 579). Hal tersebut di pengaruhi oleh :

a. Kesetaraan/Keadilan disebabkan keadilan dalam rencana master plan/site plan, distribusi ukuran dan letak kavling dan status tanah yang bukan kepemilikan masyarakat.

b. Efektifitas disebabkan keinginan masyarakat untuk tetap tinggal atau tidak ingin direlokasi/digusur dengan memperoleh sertifikat tanah dan untuk ditata agar lebih baik, teratur dan tidak kumuh

c. Responsivitas didukung oleh keadilan dalam proses identifikasi kepemilikan tanah dan bangunan, rencana master plan/site plan dan distribusi ukuran dan letak tanah kapling.

d. Efisiensi tercapai karena terjadinya efisiensi dalam distribusi letak/posisi kavling, tingginya dukungan dan komitmen pemerintah daerah, dukungan DPRD dan stake holder, penyediaan dana bantuan dan pemberian pinjaman bunga rendah serta pembiayaan proses konsolidasi tanah.

2. Keberhasilan proses konsolidasi tanah yang telah dilaksanakan tidak diikuti oleh keberhasilan dalam pelaksanaan hasil konsolidasi tanah tersebut dimana realokasi dan penataan terhenti sempat terhenti yang disebabkan oleh :

a. Efektifitas dalam hasil kesepakatan/konsesus kurang memperhatikan pengetahuan, pemahaman, kebutuhan, kecemasan dan kekhawatiran masyarakat terutama dalam pelaksanaan distribusi ukuran dan letak kapling tanah dan pemberian pinjaman kredit bunga rendah menimbulkan penolakan dimana kurangnya responsif, tidak puas/tidak dapat menerima dan ditambah dengan adanya provokasi/pengaruh dari luar yang membuat masyarakat menolak kembali hasil kesepakatan yang telah disepakati sebelumnya.

b. Ketidaksetaraan/adilan terhadap hasil konsolidasi tanah berupa distribusi ukuran dan letak kapling tanah, skema pembiayaan terhadap sebagian kecil masyarakat dapat menimbulkan protes

c. Kurangnya Efisiensi yang disebabkan oleh sempitnya luas kawasan konsolidasi tanah, tidak tersedianya biaya pembangunan dari sisa tanah hasil konsolidasi tanah dan kurangnya jumlah bantuan cuma-cuma dan pinjaman kredit bunga rendah yang disediakan pemerintah untuk biaya pembangunan dan pemulihan kembali rumah, Pendapatan masyarakat yang tidak menentu, Kurangnya pemahaman masyarakat terhadap mekanisme dan prosedur konsolidasi tanah, kurangnya kuantitas dan kualitas tenaga teknis.

\section{DAFTAR PUSTAKA}

Basri, Hassan. 2014. Laporan Pelaksanaan Proyek Perubahan Breakthrough II-Laboratorium Kepemimpinan Tingkat II Kemendagri-Inovasi Konsolidasi Penataan Perumahan Kumuh di Kabupaten Bangka Tengah. LAN RI : Tidak diterbitkan.

Doebele, William A (ed.). 1982. Land Readjustment : A Different Approach to Financing Urbanization. Toronto : LexingtonBooks

Dunn, William N. 2003. Analisis Kebijakan Publik. Yogyakarta : Gadjah Mada University Press.

Dwijowijoto, Riant Nugroho.2003. Kebijakan Publik Formulasi, Implementasi dan Evaluasi. Jakarta : PT Elex Media Komputindo Kelompok Gramedia. 
JPWK 12 (1)Yurmansah Evaluałi Proses Konsolidasi Tanah Kawasan Permukiman Kumuh Bantaran Sungai Kurau Klaster 1 Desa Kurau Berdasarkan Persepsi Masyarakat

Konursay, Sadik Yilmaz. 2004. Land Readjustment Process In Urban Design: Project Management Approach, Turkey: İzmir Institute of Technology İzmir.

Kuswartojo, Tjuk. 2010. Mengusik Tata Penyelenggaraan Lingkungan Hidup Dan Permukiman. Bandung : Kelompok Keahlian Perkim Sekolah Arsitektur Perencanaan Dan Pengembangan Kebijakan ITB.

Laporan Akhir Penyusunan Master Plan Revitalisasi Desa Kurau. Dinas Pekerjaan Umum Kabupaten Bangka Tengah. 2012.

Mittal, Jay. 2014. Self-Financing Land And Urban Development Via Land Readjustment And Value Capture.Elsevier ScienceDirect : Habitat International 44 (2014) 314-323.

Profil Kawasan Kumuh Kabupaten Bangka Tengah 2014, Direktorat Pengembangan PermukimanDirektorat Jenderal Cipta KaryaKementerian Pekerjaan Umum, 2014.

Ramdani, Bani Dipra \& Ragil Haryanto. 2013. Preferensi Masyarakat Terhadap Penataan Kawasan Permukiman Nelayan Kumuh Di Desa Kurau Kecamatan Koba Kabupaten Bangka Tengah . Jurnal Teknik PWK Undip Vol. 2 Nomor 32013.

Rossi, Peter H \& E. Freeman Howard, 1921, Evaluation a systematic Approach, Third Edition. Beverly Hill London New Delhi : Sage Publication.

Sobirin. 2001. Distribusi Permukiman dan Prasarana Kota : Studi Kasus Dinamika Pembangunan Kota di Indonesia, dalam Dimensi Keruangan Kota Teori dan Kasus, UI Press, Jakarta.

Soetomo. 2006. Strategi-Strategi Pembangunan Masyarakat. Yogyakarta: Pustaka Pelajar.

Sorensen, Andre. 2000. Confict, consensus or consent: implications of Japanese land readjustment practice for developing countries. Pergamon : Habitat International 24;5173 .

- 2000a. Land Readjustment And Metropolitan Growth:An Examination Of Suburban Land Development And Urban Sprawl In The Tokyo Metropolitan Area. Pergamon : Progress in Planning 53 (2000) 217-330.

Surat Edaran Menteri Agraria/ Kepala Badan Pertanahan Nasional No. 410-1078 tanggal 18 April 1996 tentang petunjuk teknis konsolidasi pertanahan. Badan Pertanahan Nasional Republik Indonesia. 1996.

Turk, Sevkiye Sence. 2007. An Analysis On The Efficient Applicability Of The Land Readjustment (LR) Method In Turkey. Elsevier : Habitat International 31 (2007) 53-64.

UN-habitat. 2008. Perumahan Bagi Kaum Miskin Di Kota-Kota Asia, Thailand : UNESCAP.

UN-Habitat. 2012. Participatory And Inclusive Land Readjustment. http://unhabitat.org/participatory-and-inclusive-land-readjustment-pilar/. Diakses pada 04 Juli 2015 jam 14.32.

UN-Habitat. 2013. Solomon PPT Land Readjutment; Towards As Working Definition.https://www.fig.net/resources/proceedings/fig_proceedings/

fig2014/ppt/DG/Solomon.pdf. Diakses pada 04 Juli 2015 jam 14.30.

Wang, Qianyi et.al. 2014. Stakeholder Perspectives Of China's Land Consolidation Program: A Case Study Of Dongnan Village, Shandong Province. Elsevier ScienceDirect : Habitat International 43 (2014) 172-180.

Yilmaz, Ahmet. et.al. 2015. An Evaluation Framework For Land Readjustment Practices. Elsevier ScienceDirect : Land Use Policy 44 (2015) 153-168.

Yudohusodo, Siswono. 1991. Rumah Untuk Seluruh Rakyat, Direktorat Jendral Cipta Karya, Jakarta Yudohusodo, Siswono. 1991. Tumbuhnya Permukiman-Permukiman Liar di Kawasan Perkotaan, JIIS. Nomor. 1. 